\title{
Kamma Rahbeks brevveksling med Chr. Molbech
}

af cand.phil. Kirsten Dreyer

I Det kongelige Biblioteks håndskriftsamling opbevares en af de ejendommeligste og mest fængslende korrespondancer fra guldaldertidens Danmark. Det drejer sig om mere end 300 breve, som Kamma Rahbek (1775-1829) og Christian Molbech (1783-1857) skrev til hinanden i årene 1813 til 1828. Brevvekslingen har været alment kendt og ofte diskuteret, siden den blev udgivet i uddrag i 1883, men nu er den netop blevet udgivet i sin helhed i Det kongelige Biblioteks skriftrække Danish Humanist Texts and Studies (Volume 6, I-III. 1993-94). Dermed skulle det forhåbentlig være muligt, at analysen og diskussionen i fremtiden kan ske på en fyldigere og mere nuanceret baggrund end hidtil, hvor man som oftest har stemplet Kammas og Molbechs venskab som en ret ordinær kærlighedshistorie ud fra en mere eller mindre moralsk synsvinkel.

Denne vurdering er dog ikke helt uforståelig. Dels giver udvalget af breve i 1883-udgaven et skævt billede af venskabet, dels er brevvekslingens intensitet næppe typisk for et almindeligt venskab mellem en mand og en kvinde. Hovedparten af brevene, nemlig 265 af de ialt 303 breve, er skrevet på mindre end to år i tiden fra 22.3.1813 til 17.12.1814. Bag denne skæve vægtfordeling skjuler sig imidlertid ikke en kærlighedshistorie, men dels en psykologisk interessant beretning om et krisefyldt venskab, der nok opløses, men aldrig afbrydes totalt, og dels en historie, der har ikke så få lighedspunkter med 1800-tallets dannelsesroman. Men der er også andre grunde til, at korrespondancen altid har påkaldt sig interesse. Den er således en af de vigtigste kilder til forståelsen af Kamma Rahbeks personlighed og den største og mest komplette brevveksling, der er bevaret fra hendes hånd. Og sidst men 


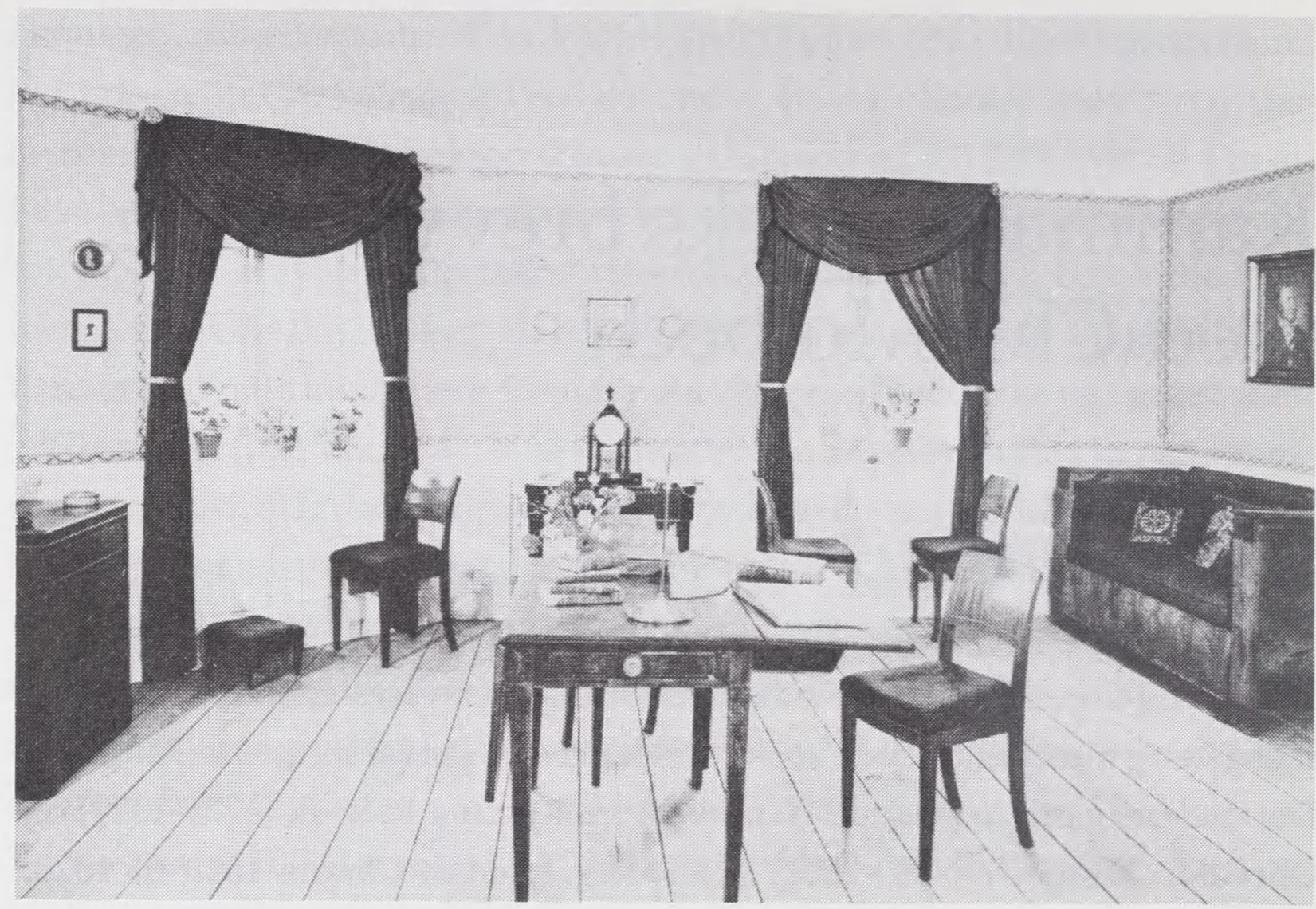

Bakkehuset. Kamma Rahbeks hjørnestue. I forgrunden hendes kombinerede arbejds- og spisebord. Til højre sofaen, hvor hun døde i Rahbeks arme den 21. januar 1829. Fotografi. Frederiksberg Lokalhistoriske Samling.

ikke mindst er den en righoldig kilde til belysning af livet på Bakkehuset, Kammas og Knud Lyne Rahbeks hjem på det dengang landlige Frederiksberg. Her skabte de et samlingssted, hvor næsten alle guldaldertidens kulturpersonligheder havde deres gang gennem mere end 30 år. Det var mænd som P.A. Heiberg, Baggesen, Oehlenschläger, J.P. Mynster, Ingemann, Poul M. Møller og H.C. Andersen, der hørte til Bakkehusets store vennekreds. Kvinderne spillede derimod en mere underordnet rolle. Mange blev skræmt af Kammas intelligens, belæsthed og skarpe vid.

Det er ikke tilfældigt, at brevskrivningen kulminerede i 1800-tallet før opfindelsen af telefonen, for de fleste privatbreve fungerede som erstatning for den personlige samtale. Som regel boede brevskriverne langt fra hinanden, og brevet var den eneste kommunikationsmulighed. Anderledes forholder det sig med Kammas og Molbechs brevveksling. Den blev tværtimod ført mellem to mennesker, der boede i umiddelbar nærhed af hinanden. Og de mødtes jævnligt, hvad enten Molbech tog turen ud til Bakkehuset eller Kamma kom til København for at gå i kirke, næsten det eneste sted hun 
kom i byen. Derfor kom brevene sjældent til at erstatte det personlige samvær, men fungerede i stedet som et værdifuldt supplement til samtalen. Her kunne de udtale, hvad tidens omgangstone ikke tillod en kvinde og en mand at sige mundtlig, og her var stedet for den mere dybsindige refleksion.

Når brevvekslingen fik denne specielle karakter, hang det sammen med deres venskab. Det hele indgik nemlig i et større menneskeligt og psykologisk projekt, som kunne kaldes "Molbechs dannelse til et lykkeligt og harmonisk menneske under Kamma Rahbeks vejledning". Man kan sige, at de indgik en pagt, der har visse ligheder med Karen Blixens og Thorkild Bjørnvigs omkring 140 år senere.

Baggrunden for dette projekt skal søges i Kammas og Molbechs liv før 1813, hvor man også finder en del af årsagerne til, at det var dømt til at mislykkes lige fra starten.

Karen Margrethe Rahbek, som hun egentlig hed, var, hvad man i ældre sprogbrug kaldte en skønånd, og det er udelukkende hendes breve og værtskabet på Bakkehuset, der har sikret hende en plads i dansk litteraturhistorie. Hun stammede fra det velhavende borgerskab. Hjemmet i Nørregade var præget af oplysningstidens ånd og kultur, og faderens, assessor og brygger Hans Hegers, mange interesser spændte lige fra møbelsnedkeri og paparbejder til astronomi og sprogstudier. Det var interesser, datteren for en stor dels vedkommende arvede. Kamma Rahbek fik da også den bedst tænkelige uddannelse, en pige fra borgerskabet kunne få på den tid. Hun gik i et af de mest ansete pigeinstitutter, og hvad hun ikke lærte i skolen, sørgede faderen selv for at lære hende. Det gjaldt bl.a. de romanske sprog. Også i musik og tegning fik hun undervisning. Således havde hun den unge og endnu ukendte Thorvaldsen til tegnelærer. Han skændte i øvrigt altid på hende, fordi hun bildte sig ind, at hun manglede evner, fremgår det af et brev til Molbech (I 268).

Allerede i sin tidlige barndom var Kamma et dybt reflekterende menneske. Barndomshjemmet var ikke særlig religiøst, og det må ses som noget af et oprør og udtryk for et savn, da hun kort efter sin konfirmation på eget initiativ opsøgte J.G.C. Adler, der var præst ved den tyske Friedrichs Kirche (nu Christianskirken) på Christianshavn 1785-1792. Gang på gang vender hun tilbage til hans betydning i brevene til Molbech, klarest måske 23.4.1813: "Gud velsigne ham, fordi han saa kraftig hialp til at bøie min Villie til det 
Kamma Rahbek. Silhouet. Kort- og Billedafdelingen

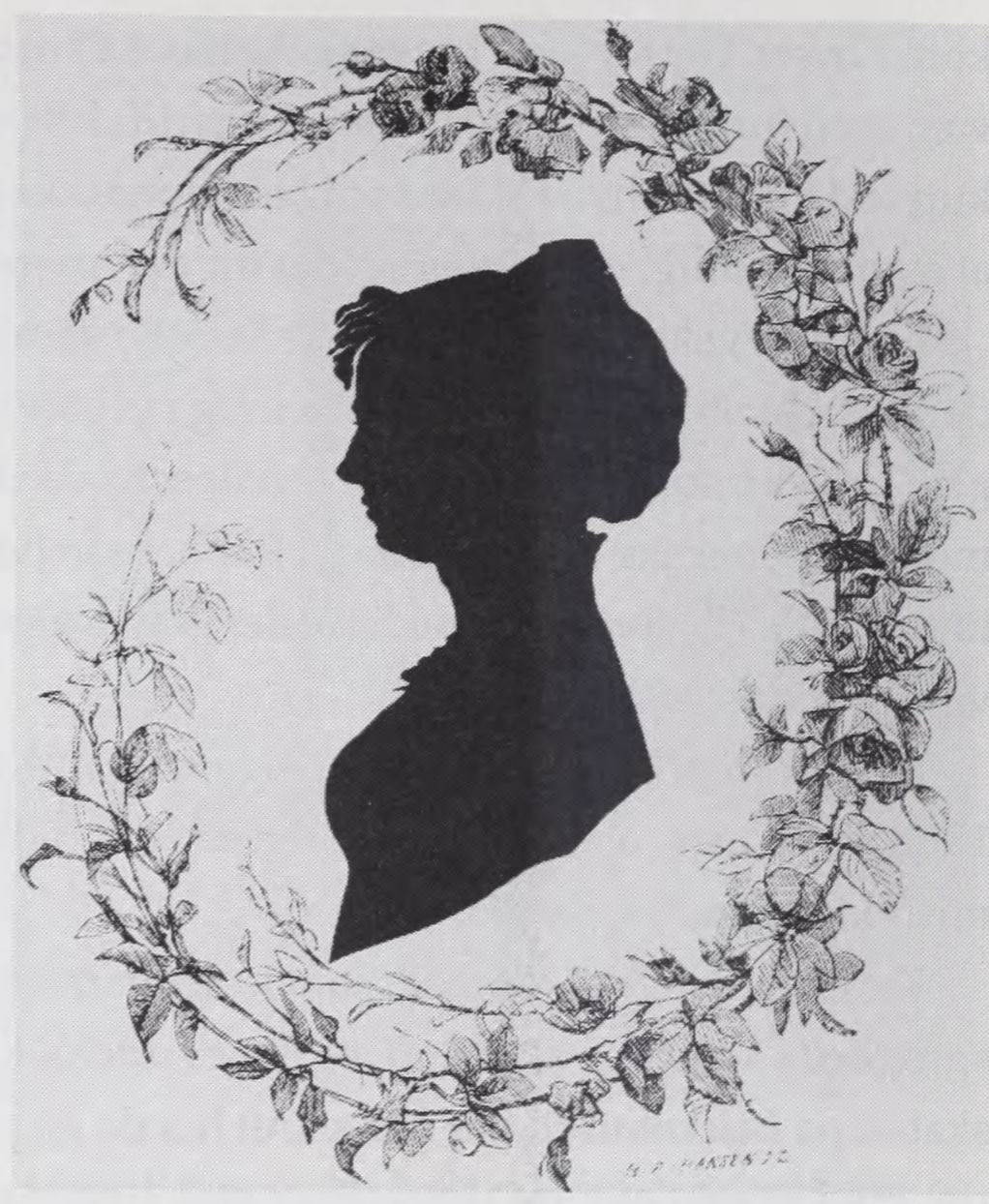

Gode, just i den Alder, hvor de gode Indtryk desværre ligesaa let forsvinde, som de frembringes" (I 90). Og ved det gode forstod Adler, der prædikede en blanding af rationalisme og pietisme, et moralsk uangribeligt liv præget af forsagelse og næstekærlighed som vejen til frelse.

Når den forkyndelse talte så stærkt til Kamma, hang det nok ikke alene sammen med hendes psyke men også med hendes svage helbred. I øvrigt led hun af hypokondri, som Molbech kommenterer på humoristisk vis: "jeg beundrer i høieste Grad, hvor De faaer al den Sundhed fra til saamegen Sygelighed" (I 63).

I 1798 blev Kamma gift med Knud Lyne Rahbek (1760-1830), der var hendes store modsætning. Selv om ægteskabet måske ikke var præget af de store lidenskaber, så var de tæt knyttet til hinanden i gensidig sympati og respekt. Brevene til Molbech viser ofte hendes omsorg og bekymring for Rahbeks befindende, men de afspejler også, at ægteskabet var præget af tolerance og fordomsfrihed. Det gav hende netop den mulighed for at udfolde sin personlighed i et omfang, som var sjældent i datiden. Desuden forenedes de i deres kærlighed til Bakkehuset, hvor Kamma skabte en have, som var berømt i samtiden. 


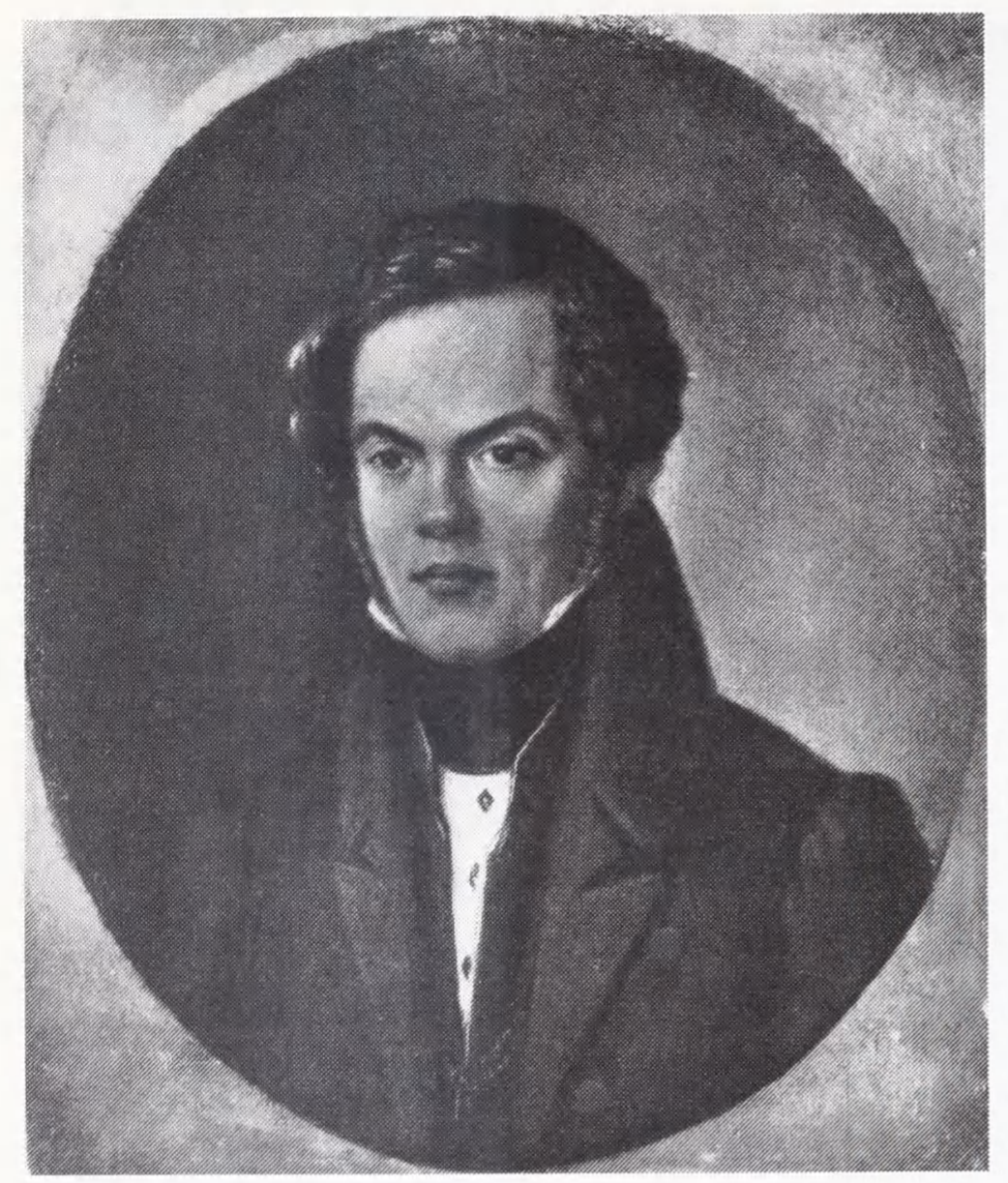

Christian Molbech (17831857) var ikke alene en flittig brevskriver. Fra 1804 til sin død var han tilknyttet Det kongelige Bibliotek som bibliotekar, men var også tidsskriftredaktør, professor i historie og direktør for Det kgl. Teater, men huskes især for sin store danske ordbog.

Maleri af ukendt kunstner. Frederiksborg Slot.

Kamma og Rahbek elskede børn. Det ser man bl.a. i et situationsbillede i et brev til Molbech: " Nu kom Ole Lund igien og bragte mig Sigvard, som en Ribstyv, og jeg havde stor Møie med at spille den strænge Rolle, der blev mig paalagt saaledes, at Drengen ikke kunde mærke det var en Rolle" (II 587). Derfor var det et savn, at ægteskabet blev barnløst. I stedet tog de Johan Ludvig Heiberg til sig som plejebarn i 1802 efter faderen, P.A. Heibergs landsforvisning og skilsmisse fra hustruen Thomasine (Gyllembourg). Det blev en fiasko. Heiberg flygtede fra Bakkehuset i 1804, og der var skyld på begge sider. Kamma var den, der tog sig det mest nær, fordi hun på grund af sit religiøse standpunkt stillede meget strenge - og urealistiske - krav til sig selv.

Men hjælpen kom, da hun i efteråret 1804 stiftede bekendtskab med præsten J.P. Mynster (1775-1854) i Spjellerup. Gennem en intens brevveksling prøvede han at få hende til at forstå, at troen og ikke gerningerne og det moralsk uangribelige liv var betingelsen for frelsen. Det var en langvarig proces, og da Kamma traf Molbech i 1812, var hun langtfra afklaret. Men hun mente, "at det staaer i ethvert godt Menneskes Magt, at skabe sig et Paradis overalt, og under alle Omstændigheder" (I 60). Og hun troede også 
at have fundet sin plads i tilværelsen: "Det er sikkert ogsaa Guds Bestemmelse med mig, at jeg skal være saameget for mine Venner, som han gav mig Evne til at kunne være; og naar jeg med redeligt Sind stræber at opfylde de Pligter, jeg skylder disse Venner, som ikke Hændelsen, men Guds vise Styrelse, og mit eget Hierte skiænkede mig, saa har jeg vist heller ikke levet forgiæves paa Jorden" (I 345). Disse synspunkter blev skæbnesvangre for deres venskab.

Christian Molbech var født i det idylliske Sorø. Barndommen var dog alt andet end lys og lykkelig. Familiens økonomi var dårlig, efter at faderen, der var lærer på akademiet, mistede sit arbejde og kom på ventepenge ved akademiets nedlæggelse i 1793. Og moderen led af tungsind, et karaktertræk sønnen arvede. Efter studentereksamen begyndte Molbech at studere jura men afbrød studierne og blev i stedet knyttet til Det kgl. Bibliotek i 1804, hvor han efterhånden avancerede til 1. sekretær. Ved siden af dette arbejde gjorde han sig bemærket som videnskabsmand, tidsskriftredaktør og digter. Men trods ydre succes var han langtfra lykkelig. Tungsindet og en ulykkelig kærlighed havde gjort ham til romantiker af den elegiske type, omend han hverken var filosofisk eller religiøst afklaret, da han blev introduceret på Bakkehuset af kollegaen E.C. Werlauff 17.12.1812.

Kammas første indtryk af Molbech var langt fra positivt, og hun var blevet advaret mod hans bekendtskab på forhånd. Men tre måneder og et besøg senere tog hun alligevel mod hans opfordring til at indlede en brevveksling og accepterede at blive hans opdragende veninde. Opgaven viste sig imidlertid umulig. Dertil var deres livssyn for forskellige. Kamma var altid hensynsløs ærlig, foragtede enhver form for affektation og kunne le af sig selv modsat Molbech, der var blottet for humor og selvkritik. Men hun havde én fejl. Trods sit ellers skarpe blik for menneskelige svagheder, som bl.a. gav sig udtryk i det såkaldte Bakkehussprog med øgenavne på mange af kredsens medlemmer, følte hun trang til at idealisere sine venner, når hun først have fattet sympati for dem. Derfor var hun længe om at opdage, at Molbech ikke var indtillet på at følge hendes leveråd, men i stedet, at det var hende selv, der ikke klarede opgaven godt nok.

I januar 1814 kom det til en alvorlig krise, da Molbech havde forelsket sig i Kammas genbo og veninde Johanne Langberg (1793-1879). Stik imod venskabs krav om åbenhed og gensidig tillid ville han ikke indrømme sine fø- 
Johanne Langberg (1793-1879), i Bakkehussproget kaldet Grevebarnet, blev i 1820 gift med Chr. Molbech.

Miniaturemaleri af Chr. Hornemann. Det kongelige Bibliotek.

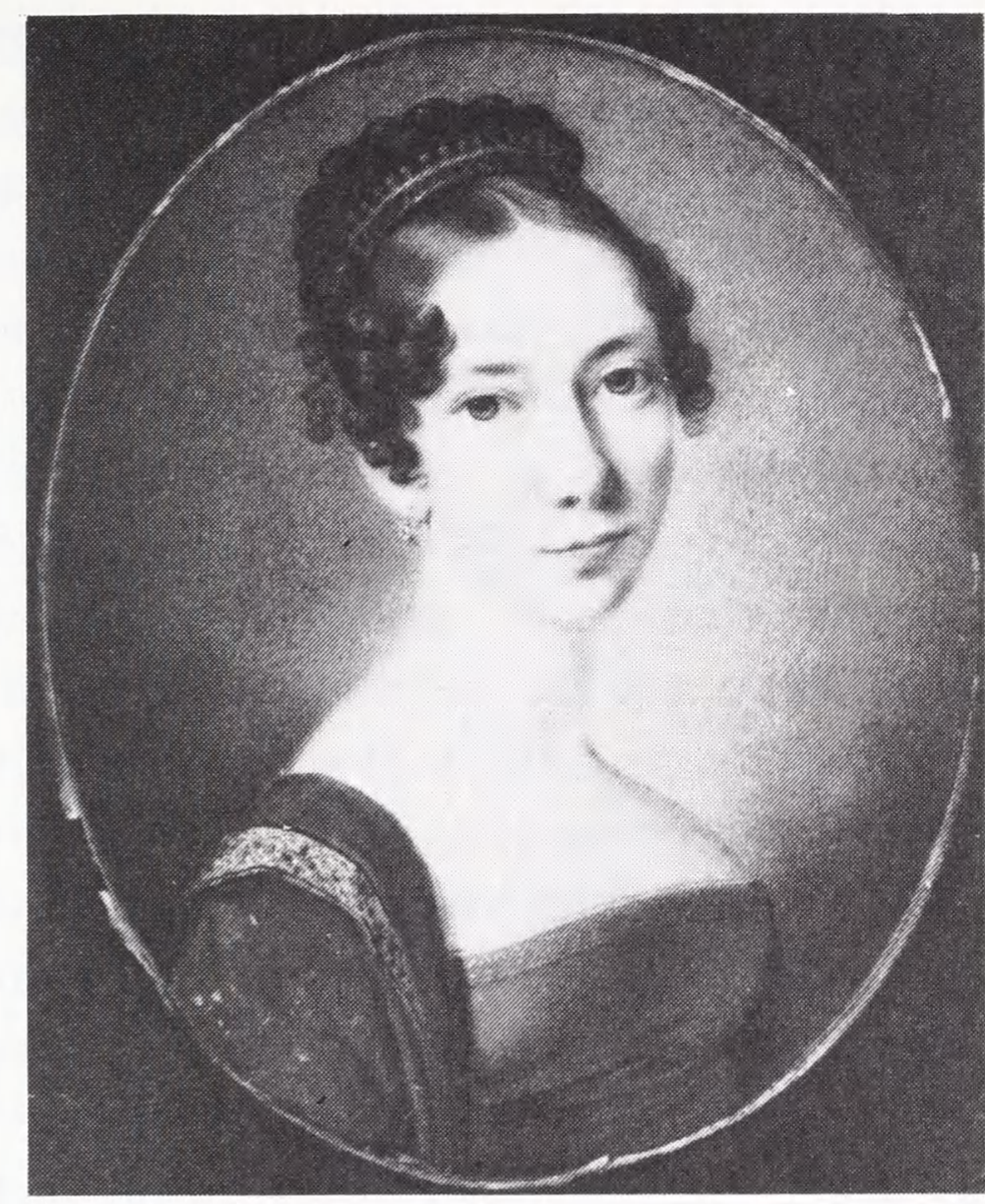

lelser, og da det endelig skete, var det i vendinger, så Kamma ikke kunne tro på følelsernes dybde og alvor. Det fik hende til at opgive troen på sin rolle som opdragende veninde, og hun begyndte at forstå, at Molbech i virkeligheden nød sit eget tungsind. Brevvekslingen og venskabet ophørte dog ikke, men deres forhold fik mere og mere karakter af en kamp mellem to stærke personligheder om, hvem der skulle frigøre sig først. Det blev Kamma, der tog det afgørende skridt, da Molbech forsøgte at anfægte oprigtigheden i hendes kristne tro og dermed hele hendes personlige integritet. Fra årsskiftet ebbede brevvekslingen ud, og Molbechs besøg blev sjældnere og ophørte en periode fuldstændigt, da han mærkede, at han ikke var velkommen. Forbindelsen blev dog aldrig helt afbrudt, og det kom til en slags forsoning, da Molbech blev forlovet med Johanne Langberg i 1819.

Molbechs dannelsesprojekt mislykkedes altså, og Kamma led et nederlag. Men ser man det i et større perspektiv, så fik venskabet alligevel en positiv betydning for hendes menneskelige udvikling. Da hun indledte brevvekslingen, var det som nævnt endnu ikke lykkedes hende at frigøre sig helt fra Adlers tro på gerningsretfærdighed. Og midt i venskabets værste krise, da hun er opfyldt af selvbebrejdelser og mener at have svigtet Molbech, 
skriver hun, at hun "endnu ikke har grebet Klenodiet, men kun ærlig og alvorlig_tragtet derefter" (II 430). Men da hun i løbet af 1814 udsættes for Molbechs kritik af hendes personlighed og handlemåde, begunder hun at forstå, at trods hendes heftige sind, som hun selv erkendte, hun ikke kunne kontrollere, var hun ikke alene om skylden for venskabets fallit. Det er næsten, som om det er Mynster, der styrer hendes pen i det brev 9.12.1814, der på en måde blev det sidste, inden venskabet opløstes. Her fralægger hun sig både det fulde ansvar for det skete og erkender troens betydning i forhold til gerningerne: "naar Samvittighedens Stemme, i det redelig sindede Menneskes Bryst, taler Dommens skrækkelige Ord, saa vidner den dog tillige lige sanddru - om det Gode Mennesket har øvet, eller i det Mindste villet; og det er vist ogsaa vor Pligt ikke at overhøre dette sanddru Vidne. Hvo der idelig kun vilde sørge over sine Synder, uden at turde tilegne sig den Trøst, som den redelige, om endog svage Villie stedse er ledsaget af, vilde snart trætte Siælen saa aldeles, at den blev reent uduelig til alt Godt" (II 671).

Medens Molbech senere erkendte Kammas betydning for ham trods det passerede, findes tilsvarende udtalelser tilsyneladende ikke fra hendes side. Som vi har set fik venskabet imidlertid Kamma til at reflektere over sin egen personlighed og livet. Denne side af korrespondancen, hvor passager kan få karakter af aforismer eller skitser til essays, er ikke de mindst spændende. F.eks. fristes man til at trække tråde fra Kamma Rahbek til Karen Blixens forkætrede: "En Baaltale med 14 Aars Forsinkelse", når det gælder følgende udtalelse: "Jeg troer det vist, at der gives Mennesker [...] der hverken kunne eller skulle ret blive hiemme her paa Jorden; og jeg kan umuelig betvivle, at jeg hører iblandt disses Tal; ligesom jeg heller ikke kan betvivle, at dette forskiællige Forhold, føder forskiællige Pligter og at det hos den ene Deel kommer mere an paa, hvad de ere, som hos den Anden hvad de udrette i Verden" (II 509). Forskellen er næsten tidstypisk. Kamma Rahbek tænker i alment menneskelige baner begrundet $\mathrm{i}$ hendes kristne tro. Karen Blixen i kønsroller ud fra et verdsligt standpunkt.

Sluttelig må brevvekslingens kulturhistoriske værdi nævnes. På grund af brevenes hyppighed kan man næsten følge Bakkehuslivet dag for dag i 1813 og 1814. Selv om Napoleonskrigene og tabet af Norge sætter sit præg på hverdagen, vrimler det med små pudsige scener, som også tjener til at belyse Kamma Rahbeks egen personlighed og den humor, hun lagde for 
dagen. Et godt eksempel findes i et brev fra 11.9.1814 efter, at Kamma Rahbek netop har slået hovedet: "Min Broder vilde i Gaar trøste mig med, at da han for nogen Tid siden slog sit Hoved, talede han forvirret i to Dage; men jeg svarte blot: det giør Du jo ofte uden at have faaet et Slag i Hovedet; og Mynster sagde: saa føler Du vel Virkningen af det sidste Slag endnu" (II 622).

Kamma Rahbek og Christian Molbechs Brevveksling. Udgivet med indledning og kommentar af Kirsten Dreyer. Det kongelige Bibliotek. Museum Tusculanums Forlag. 1993-94. Bd. 1-3. (Danish Humanist Texts and Studies 6). Kr. 540,- 